\title{
Screening of QPM Maize Genotypes against Maydis Leaf Blight (Helminthosporium maydis) under Natural Epiphytotic Conditions
}

\author{
Naresh Thakur $^{1 *}$, R. K. Devlash ${ }^{2}$ and S. Lata ${ }^{1}$ \\ ${ }^{1}$ Department of Crop Improvement, CSK Himachal Pradesh Agricultural University, \\ Palampur (HP), India \\ ${ }^{2}$ Hill Agricultural Research and Extension Centre, CSKHPKV, Bajaura, India \\ *Corresponding author
}

\section{A B S T R A C T}

\begin{tabular}{|l|}
\hline Key w or d s \\
$\begin{array}{l}\text { Maydis leaf blight, } \\
\text { QPM, Natural } \\
\text { epiphytotic, } \\
\text { Resistant }\end{array}$ \\
\hline Article Info \\
\hline $\begin{array}{l}\text { Accepted: } \\
\text { 17 January } 2021 \\
\text { Available Online: } \\
\text { 10 February } 2021\end{array}$ \\
\hline
\end{tabular}

Maydis leaf blight is considered the most devastating disease of maize crop, which causes noticeable reduction in crop yield. The present studies were undertaken to find out the stable sources of maydis leaf blight resistance. A set was obtained by crossing ten QPM inbred lines in $10 \times 10$ half diallel fashion excluding reciprocals. In total sixty lines including parents, $\mathrm{F}_{1}$ 's and standard check (HQPM-1, HQPM-4, HQPM-7, PRATAP QPM-1 and VIVEK QPM-9) were evaluated against leaf blight (Exserohilum turcicum) of maize under field conditions during kharif 2016 and 2017. One QPM inbred CML162, two QPM check VIVEK QPM-9, HQPM-1 and 17 hybrids viz., CML189 × CML163, CML180 × CML170, CML193 × CML170, CML170 × CML163, BAJIMQ-08-26 × CML189, BAJIMQ-08-27 × CML171, CML180 × BAJIMQ-08-27, CML193 × CML171, CML180 × CML163, CML170 × CML161, CML189 × CML162, CML193 × CML163, CML180 × BAJIMQ-08-26, CML193 × BAJIMQ-08-26, CML189 × CML171, BAJIMQ08-26 $\times$ CML170, CML180 $\times$ CML162 showed resistant reaction against maydis leaf blight. Twenty three crosses, seven parents and two checks were found moderately resistant and five crosses one QPM check and two inbreds were found moderately susceptible Thus, the identified resistant genotypes could be utilized for developing promising maize hybrids with inbuilt resistance to maydis leaf blight disease of maize.

\section{Introduction}

Maize (Zea mays L. $2 \mathrm{n}=20$ ) is one of the oldest and most important cereal crops in the world and cultivated in almost 150 countries. The foremost producing countries are USA, China, Brazil, Mexico, France and India. Maize contributes to food security in most of the developing countries and globally, maize grown in an area of 197.20 million hectare with production of 1148.49 million tonnes and productivity 58.24 quintals per hectare (FAO STAT, 2019).

India is the $2^{\text {nd }}$ most important maize growing country in Asia and world's $6^{\text {th }}$ largest producer and the $5^{\text {th }}$ largest consumer and cultivated in an area of 9.63 million hectare with production of 25.90 million tonnes and productivity of 26.89 quintals per hectare 
(kharif and rabi). In Himachal Pradesh, it is an important kharif crop grown in an area of 0.29 million hectares with a total production of 0.78 million tonnes and productivity of 26.72 quintals per hectare as compared to the national average of 24.13 quintals per hectare in kharif season (Anonymous, 2017). It is potentially proficient of producing large quantities of food grain in short duration and can effectively solve the food problems of soaring population of our country (Upadhyay and Palanivel, 2011). In India maize is used as for feed $(63 \%)$, food $(23 \%)$, starch industries $(12 \%)$, seed and miscellaneous use $(2 \%)$.

Maize is prone to as many as 112 diseases in different parts of the globe, out of which about 61 diseases have been reported to affect the crop in India (Wani, 2015). Primary diseases include seed rots and seedling blights, root and stalk rots, foliar diseases and ear rots etc. (Kumar et al., 2013). Out of these maydis leaf blight caused by the fungus Helminthosporium maydis Nisikado (teleomorph Cochliobolus heterostrophus Dreshch.) is a serious foliar disease of maize distributed widely in maize growing area across the world and has attained the status of the economically important disease (Malik et al., 2017).

Leaf blight leads to yield reduction (41\%) and also deteriorate the value and quality of the maize grain. Symptoms of maydis leaf blight on leaf appears initially as small and diamond shaped lesions, as they mature lesion get elongated. Maydis leaf blight also known as South Corn Leaf Blight (SCLB) because of its preponderance in the South America.

The disease is widely distributed in India during kharif season. In India, maydis blight appears in hills, plains and peninsular parts and require warm $\left(20\right.$ to $\left.32^{\circ} \mathrm{C}\right)$ and humid (more than $80 \%$ ) conditions to grow. Three races of Cochliobolus heterostrophus known as $\mathrm{O}, \mathrm{T}$ and $\mathrm{C}$ has been described and currently predominant form of Cochliobolus heterostrophus is Race $\mathrm{O}$, in severity, which can cause yield losses of up to $40 \%$ (Gregory et al., 1978; Byrnes et al., 1989).

The literature related to dominancy of the pathogen causing maydis leaf blight under Himachal Pradesh is limited and also there is an urgency to identify the maydis leaf blight resistance source. Therefore, research was aimed to determine the resistance level of different maize inbred lines genotype against the disease through the process of screening and evaluation because of its prime importance to address the fungal disease. As a consequence the knowledge acquired from the study might be of vital use for the scientific research of phytopathologists, plant breeders and also for the farmers.

\section{Materials and Methods}

The materials screened in the present study comprised ten QPM inbred lines (Table 1) and inbred lines were crossed in a $10 \times 10$ half diallel mating system excluding reciprocals during kharif 2015.

Field experiment was conducted at Experimental Farm of the Department of Crop Improvement, College of Agriculture, CSK HPKV, Palampur situated at $1290.8 \mathrm{~m}$ amsl having latitude $32^{\circ} 6^{\prime} \mathrm{N}$ and longitude 76 $3^{\circ}$ ' E during kharif 2016 and 2017.

The experiment was designed in RBD with single replications in a plot size of $2.0 \times 0.60$ $\mathrm{m}\left(1.2 \mathrm{~m}^{2}\right)$ at spacing of $60 \times 20 \mathrm{~cm}$. Seeds of eight QPM inbred lines viz., CML161, CML162, CML163, CML170, CML171, CML180, CML189 and CML193 from Indian Institute of Maize Research (IIMR), New Delhi and two lines were procured from HAREC Bajaura (Kullu). The chemical 
fertilizer was applied at the rate of 120:60:40 $\mathrm{kg} \mathrm{NPK} /$ ha through urea $(46 \% \mathrm{~N})$, DAP (18\% $\mathrm{N}$ and $\left.46 \% \mathrm{P}_{2} \mathrm{O}_{5}\right)$ and $\mathrm{MOP}\left(60 \% \mathrm{~K}_{2} \mathrm{O}\right)$ along with FYM @ 10 t/ha. Half dose of nitrogen and full dose of phosphorus and potassium were applied as a basal dose during final land preparation and remaining half dose of $\mathrm{N}$ was top dressed 45 days after sowing (DAS). Thinning was done 30 days after sowing in all plots to maintain desired plant population.

To control borer, 3 to 4 furadane granules were applied once to the whorl of each plant manually at 45 DAS. Two manual weedings and hoeings were done at knee high stage and before tasseling to control weeds. Disease reaction of the lines and crosses were recorded for turcicum leaf blight. The disease reaction were recorded for leaf blight as per scale used 0-5 (Chenulu and Hora, 1962).

\section{Results and Discussion}

All the genotypes showed significant variation in disease reaction. Perusal of data presented in Table 2 indicated that all the genotypes showed resistant to susceptible reaction against maydis leaf blight of maize.

The results revealed that the maydis leaf blight reaction during both the years kharif 2016 and 2017 varied from 1.0 to 3.5, indicating good segregation among genotypes. Out of 60 genotypes, one parent CML162, two QPM check VIVEK QPM-9, HQPM-1 and 17 hybrids viz., CML189 $\times$ CML163, CML180 × CML170, CML193 × CML170, CML170 × CML163, BAJIMQ-08$26 \times$ CML189, BAJIMQ-08-27 × CML171, CML180 $\times$ BAJIMQ-08-27, CML193 $\times$ CML171, CML180 $\times$ CML163, CML170 $\times$ CML161, CML189 × CML162, CML193 × CML163, CML180 $\times$ BAJIMQ-08-26, CML193 $\times$ BAJIMQ-08-26, CML189 $\times$ CML171, BAJIMQ-08-26 × CML170,
CML180 $\times$ CML162 showed resistant reaction against maydis leaf blight. Twenty three crosses viz., CML170 × CML162, CML193 $\times$ BAJIMQ-08-27, CML170 $\times$ CML162, CML171 $\times$ CML162, CML189 $\times$ CML161, BAJIMQ-08-26 × CML163, CML180 × CML171, CML163 × CML161, CML171 $\times$ CML170, CML180 $\times$ CML93, CML171 $\times$ CML163, BAJIMQ-0-27 $\times$ BAJIMQ-08-26, BAJIMQ-08-26 × CML171, BAJIMQ-08-27 $\times$ CML161, BAJIMQ-08-26 $\times$ CML189, CML180 × CML161, CML193 × CML161, CML193 × CML189, BAJIMQ-08$26 \times$ CML162, CML171 $\times$ CML161, BAJIMQ-08-26 × CML161, BAJIMQ-08-27 $\times$ CML163, CML180 × CML189, seven parents namely BAJIMQ-08-26, CML170, CML180, BAJIMQ-08-27, CML161, CML193, CML171 and two checks viz., PRATAP QPM-1 and HQPM-7 were found moderately resistant with disease score of 2.0 (Table 3) and five crosses viz., BAJIMQ-08$27 \times$ CML170, CML163 $\times$ CML162, CML193 $\times$ CML162, CML189 $\times$ CML170, BAJIMQ-08-27 × CML162, one QPM check i.e. HQPM-4 and two inbreds viz., CML163, CML189 were found moderately susceptible with mean disease score 3.0. None of the crosses, parents and checks was found susceptible/highly susceptible during kharif 2016 and 2017.

Various research findings on maydis leaf blight were reported, which support the present results (Kumar and Saxena, 2008; Chandrashekara et al., 2014; Goudar and Harlapur, 2016; Singh et al., 2018). Kumar and Saxena (2008) reported that one genotype was moderately resistant and seven genotypes were moderately susceptible. Rai et al., (2010) evaluated fifty one genotypes and found twenty six resistant, eight moderately resistant, thirteen moderately susceptible, two susceptible and two highly susceptible. 
Table.1 Description of the QPM inbred lines used in the investigation

\begin{tabular}{|l|l|l|l|}
\hline $\begin{array}{l}\text { Sr. } \\
\text { No. }\end{array}$ & Material & Pedigree & Source \\
\hline 1. & CML161 $\left(\mathrm{P}_{1}\right)$ & G25Q $18 M H 520$ & IIMR, New Delhi \\
\hline 2. & CML162 $\left(\mathrm{P}_{2}\right)$ & G25Q 1 1 HC18-8-1-2-B-B-2-B-B-B & IIMR, New Delhi \\
\hline 3. & CML163 $\left(\mathrm{P}_{3}\right)$ & G26QMH31-2-2-\#-2-2-1-B-1-B-B-\# & IIMR, New Delhi \\
\hline 4. & CML170 $\left(\mathrm{P}_{4}\right)$ & G26Q $22 M H 9-3-1-5-1-B-B$ & IIMR, New Delhi \\
\hline 5. & CML171 $\left(\mathrm{P}_{5}\right)$ & G25Q54B-MH13-5-B-1-1-2-B-1-B-B-B & IIMR, New Delhi \\
\hline 6. & CML189 $\left(\mathrm{P}_{6}\right)$ & G34QMH17-2-1-1-B & IIMR, New Delhi \\
\hline 7. & BAJIMQ-08-26 $\left(\mathrm{P}_{7}\right)$ & Baj Poo195- $\otimes-26-8-4-1-6-1-1-B-B-B-Q$ & CSK HPKV, Palampur \\
\hline 8. & BAJIMQ-08-27 $\left(\mathrm{P}_{8}\right)$ & Baj Poo198- $\otimes-83-10-1-6-1-1-B-B-Q$ & CSK HPKV, Palampur \\
\hline 9. & CML193 $\left(\mathrm{P}_{9}\right)$ & CY0162-B-1-1-B & IIMR, New Delhi \\
\hline 10. & CML180 $\left(\mathrm{P}_{10}\right)$ & $(\mathrm{C} 32 \mathrm{Q} /$ EV8444SRBC4)\#-B-\#-B-B-21-2- & IIMR, New Delhi \\
\hline
\end{tabular}

*BAJIMQ- Bajaura QPM converted inbred maize, CML- CIMMYT maize lines

Table.2 Disease score of maize genotypes to maydis leaf blight (MLB) under natural epiphytotic conditions during kharif 2016 and 2017

\begin{tabular}{|l|l|l|l|l|}
\hline & & \multicolumn{3}{l|}{ MLB (Natural epiphytotic conditions) } \\
\hline Sr. No. & Genotypes & $\mathbf{2 0 1 6}$ & $\mathbf{2 0 1 7}$ & Mean \\
\hline $\mathbf{1 .}$ & CML162 $\times$ CML161 & 2.00 & 2.00 & 2.00 \\
\hline $\mathbf{2 .}$ & CML163 $\times$ CML161 & 2.00 & 2.00 & 2.00 \\
\hline $\mathbf{3 .}$ & CML170 $\times$ CML161 & 1.00 & 1.00 & 1.00 \\
\hline $\mathbf{4 .}$ & CML171 $\times$ CML161 & 2.00 & 2.00 & 2.00 \\
\hline $\mathbf{5 .}$ & CML189 $\times$ CML161 & 2.50 & 1.50 & 2.00 \\
\hline $\mathbf{6 .}$ & BAJIMQ-08-26 $\times$ CML161 & 2.00 & 2.00 & 2.00 \\
\hline $\mathbf{7 .}$ & BAJIMQ-08-27 $\times$ CML161 & 2.00 & 2.00 & 2.00 \\
\hline $\mathbf{8 .}$ & CML193 $\times$ CML161 & 2.00 & 2.00 & 2.00 \\
\hline $\mathbf{9 .}$ & CML180 $\times$ CML161 & 1.50 & 2.50 & 2.00 \\
\hline $\mathbf{1 0 .}$ & CML163 $\times$ CML162 & 3.00 & 3.00 & 3.00 \\
\hline $\mathbf{1 1 .}$ & CML170 $\times$ CML162 & 2.00 & 2.00 & 2.00 \\
\hline $\mathbf{1 2 .}$ & CML171 $\times$ CML162 & 2.00 & 2.00 & 2.00 \\
\hline $\mathbf{1 3 .}$ & CML189 $\times$ CML162 & 1.00 & 1.00 & 1.00 \\
\hline $\mathbf{1 4 .}$ & BAJIMQ-08-26 $\times$ CML162 & 2.00 & 2.00 & 2.00 \\
\hline $\mathbf{1 5 .}$ & BAJIMQ-08-27 $\times$ CML162 & 3.50 & 2.50 & 3.00 \\
\hline $\mathbf{1 6 .}$ & CML193 $\times$ CML162 & 3.00 & 3.00 & 3.00 \\
\hline $\mathbf{1 7 .}$ & CML180 $\times$ CML162 & 1.00 & 1.00 & 1.00 \\
\hline $\mathbf{1 8 .}$ & CML170 $\times$ CML163 & 1.00 & 1.00 & 1.00 \\
\hline
\end{tabular}




\begin{tabular}{|c|c|c|c|c|}
\hline 19. & CML171 × CML163 & 2.00 & 2.00 & 2.00 \\
\hline 20. & CML189 × CML163 & 1.00 & 1.00 & 1.00 \\
\hline 21. & BAJIMQ-08-26 × CML163 & 2.00 & 2.00 & 2.00 \\
\hline 22. & BAJIMQ-08-27 × CML163 & 2.00 & 2.00 & 2.00 \\
\hline 23. & CML193 × CML163 & 1.00 & 1.00 & 1.00 \\
\hline 24. & CML180 × CML163 & 1.00 & 1.00 & 1.00 \\
\hline 25. & CML171 × CML170 & 2.00 & 2.00 & 2.00 \\
\hline 26. & CML189 × CML170 & 2.50 & 2.50 & 2.50 \\
\hline 27. & BAJIMQ-08-26 × CML170 & 1.00 & 1.00 & 1.00 \\
\hline 28. & BAJIMQ-08-27 × CML170 & 3.00 & 3.00 & 3.00 \\
\hline 29. & CML193 × CML170 & 1.00 & 1.00 & 1.00 \\
\hline 30. & CML180 $\times$ CML170 & 1.00 & 1.00 & 1.00 \\
\hline 31. & CML189 × CML171 & 1.00 & 1.00 & 1.00 \\
\hline 32. & BAJIMQ-08-26 × CML171 & 2.00 & 2.00 & 2.00 \\
\hline 33. & BAJIMQ-08-27 × CML171 & 1.00 & 1.00 & 1.00 \\
\hline 34. & CML193 × CML171 & 1.00 & 1.00 & 1.00 \\
\hline 35. & CML180 × CML171 & 2.00 & 2.00 & 2.00 \\
\hline 36. & BAJIMQ-08-26 × CML189 & 1.00 & 1.00 & 1.00 \\
\hline 37. & BAJIMQ-08-27 × CML189 & 2.00 & 2.00 & 2.00 \\
\hline 38. & CML193 × CML189 & 2.00 & 2.00 & 2.00 \\
\hline 39. & CML180 × CML189 & 2.00 & 2.00 & 2.00 \\
\hline 40. & BAJIMQ-08-27 × BAJIMQ-08-26 & 2.00 & 2.00 & 2.00 \\
\hline 41. & CML193× BAJIMQ-08-26 & 1.00 & 1.00 & 1.00 \\
\hline 42. & CML180 × BAJIMQ-08-26 & 1.00 & 1.00 & 1.00 \\
\hline 43. & CML193 × BAJIMQ-08-27 & 2.00 & 2.00 & 2.00 \\
\hline 44. & CML180 × BAJIMQ-08-27 & 1.00 & 1.00 & 1.00 \\
\hline 45. & CML180 × CML193 & 2.00 & 2.00 & 2.00 \\
\hline 46. & HQPM-4 & 3.00 & 3.00 & 3.00 \\
\hline 47. & HQPM-7 & 2.00 & 2.00 & 2.00 \\
\hline 48. & Pratap QPM-1 & 2.00 & 2.00 & 2.00 \\
\hline 49. & CML161 & 2.00 & 2.00 & 2.00 \\
\hline 50. & CML162 & 1.00 & 1.00 & 1.00 \\
\hline 51. & CML163 & 2.50 & 3.50 & 3.00 \\
\hline 52. & CML170 & 2.00 & 2.00 & 2.00 \\
\hline 53. & CML171 & 2.00 & 2.00 & 2.00 \\
\hline 54. & CML189 & 3.00 & 3.00 & 3.00 \\
\hline 55. & BAJIMQ-08-26 & 2.00 & 2.00 & 2.00 \\
\hline 56. & BAJIMQ-08-27 & 2.00 & 2.00 & 2.00 \\
\hline 57. & CML193 & 1.50 & 2.50 & 2.00 \\
\hline 58. & CML180 & 2.00 & 2.00 & 2.00 \\
\hline 59. & HQPM-1 (SC-1) & 1.00 & 1.00 & 1.00 \\
\hline 60. & Vivek QPM-9 (SC-2) & 1.00 & 1.00 & 1.00 \\
\hline
\end{tabular}


Table.3 Disease Reaction of QPM maize genotypes to maydis leaf blight (MLB) during kharif 2016 and 2017 under natural epiphytotic condition

\begin{tabular}{|c|c|c|c|}
\hline $\begin{array}{l}\text { Disease } \\
\text { Score }\end{array}$ & Reaction & $\begin{array}{l}\text { Parents/hybrids/QPM } \\
\text { checks }\end{array}$ & Crosses \\
\hline $\mathbf{0}$ & $\begin{array}{l}\text { Highly } \\
\text { resistant }\end{array}$ & - & - \\
\hline 1 & Resistant & $\begin{array}{l}\text { CML162, VIVEK } \\
\text { QPM-9, HQPM-1 }\end{array}$ & $\begin{array}{l}\text { CML189 × CML163, CML180 × CML170, } \\
\text { CML193 × CML170, CML170 × CML163, } \\
\text { BAJIMQ-08-26 × CML189, BAJIMQ-08-27 × } \\
\text { CML171, CML180 × BAJIMQ-08-27, CML193 } \times \\
\text { CML171, CML180 × CML163, CML170 } \times \\
\text { CML161, CML189 × CML162, CML193 } \\
\text { CML163, CML180 × BAJIMQ-08-26, CML193 } \times \\
\text { BAJIMQ-08-26, CML189 × CML171, BAJIMQ- } \\
\text { 08-26 } \times \text { CML170, CML180 } \times \text { CML162 }\end{array}$ \\
\hline 2 & $\begin{array}{l}\text { Moderately } \\
\text { resistant }\end{array}$ & $\begin{array}{l}\text { BAJIMQ-08-26, } \\
\text { PRATAP QPM-1, } \\
\text { CML170, CML180, } \\
\text { BAJIMQ-08-27, } \\
\text { CML161, HQPM-7, } \\
\text { CML193, CML171, }\end{array}$ & $\begin{array}{l}\text { CML170 × CML162, CML193 × BAJIMQ-08-27, } \\
\text { CML170 × CML162, CML171 × CML162, } \\
\text { CML189 × CML161, BAJIMQ-08-26 × CML163, } \\
\text { CML180 × CML171, CML163 × CML161, } \\
\text { CML171 × CML170, CML180 × CML93, } \\
\text { CML171 × CML163, BAJIMQ-0-27 × BAJIMQ- } \\
\text { 08-26, BAJIMQ-08-26 × CML171, BAJIMQ-08- } \\
27 \times \text { CML161, BAJIMQ-08-26 × CML189, } \\
\text { CML180 × CML161, CML193 × CML161, } \\
\text { CML193 × CML189, BAJIMQ-08-26 × CML162, } \\
\text { CML171 × CML161, BAJIMQ-08-26 × CML161, } \\
\text { BAJIMQ-08-27 × CML163, CML180 × CML189 }\end{array}$ \\
\hline 3 & $\begin{array}{l}\text { Moderately } \\
\text { susceptible }\end{array}$ & $\begin{array}{l}\text { CML163, CML189, } \\
\text { HQPM-4 }\end{array}$ & $\begin{array}{l}\text { BAJIMQ-08-27 × CML170, CML163 × CML162, } \\
\text { CML193 } \times \text { CML162, CML189 × CML170, } \\
\text { BAJIMQ-08-27 × CML162 }\end{array}$ \\
\hline 4 & Susceptible & - & - \\
\hline 5 & $\begin{array}{l}\text { Highly } \\
\text { susceptible }\end{array}$ & - & - \\
\hline
\end{tabular}

Note: Scale used 0-5 (Chenulu and Hora 1962)

Similarly screened 35 short-duration maize inbred lines against MLB under natural conditions and found 19 resistant lines. Goudar and Harlapur (2016) also observed that two genotypes were highly resistant, five were resistant, ten were moderately resistant, eleven were susceptible and six were highly susceptible against maydis leaf blight under field conditions. The lines so identified to possess low disease score are a valuable source and can be utilized in resistance breeding programmes. The cross combinations can be further evaluated for yield and other characters and can be released as promising hybrid varieties.

\section{References}

Anonymous. 2017. Directorate of Economics and Statistics. http://eands.dacent.nic.in.

Byrens, K.J., Pataky, J.K. and White, D.G. 1989. Relationships between yield of three maize hybrids and severity of southern leaf blight caused by race $\mathrm{O}$ of Bipolaris maydis. Plant Disease, 73: 834-840. 
Chandrasekhara, C., Jha S.K., Kumar, R. and Agrawal, P.K. 2014. Identification of new sources of resistance to turcicum leaf blight and maydis leaf blight in maize (Zea mays L.). SABRAO Journal of Breeding and Genetics, 46: 44-55.

Chenulu, W. and Hora, T.S. 1962. Studies on losses due to Helminthosporium blight of maize. Indian Phytopathology, 15: 235-237.

FAO STAT. 2019. STAT of Food and Agriculture 2019, P99.

Goudar, S. and Harlapur, S.I. 2016. Evaluation of maize inbred lines and hybrids for resistance to maydis leaf blight. Journal of Farm Science, 29: 408-409.

Gregory, L.V., Ayres, J.E. and Nelson, R.R. 1979. The influence of cultivar and location on yield loss in corn due to southern corn leaf blight (Helminthosporium maydis). Plant Disease Reporter, 63: 891-895.

Kumar, P. and Saxena, P. 2008. Performance of maize genotypes against southern leaf blight disease caused by Drechslera maydis. Journal of Mycology and Plant Pathology, 38: 389-391.

Kumar, R., Hooda, K.S., Olakh, D.S., Kaur, H., Malik, V. and Kumar, S. 2013. Reaction of QPM inbred lines against Maydis Leaf Blight (MLB) and Charcol Rot. Electronic Journal of Plant Breeding, 4 (4): 1280-1283.
Malik, V.K., Kumar, R., Jaglan, M.S. and Kamboj, M. C. 2015. Identification of new sources of resistance against maydis leaf blight (MLB) and banded leaf and sheath blight (BLSB) diseases in quality protein maize. Progressive Research - An International Journal, 10(1): 606-608.

Rai, D., Kumar, A., Kumar, M. and Prasad, R. 2010. Field screening of maize genotypes against maydis leaf blight caused by Helminthosporium maydis Nisikado and Miyake. International Journal of Plant Protection, 2: 286-288.

Singh, M., Mehra, R. and Malik, V.K. 2018. Evaluation of maize genotypes against maydis leaf blight caused by Bipolaris maydis (Nisikado and Miyake) Shoemaker under natural epiphytotic conditions. International Journal of Current Microbiology and Applied Science, 7: 1006-1013.

Upadhyay, R.P. and Palanivel, C. 2011. Challenges in achieving food security in India. Iranian Journal of Public Health, 40: 31-36.

Wani, A.T. 2015. Status and management of turcicum leaf blight of maize (Exserohilum turcicum (Pass.) Leonard and Suggs.) in Kashmir Valley. Ph. D. Thesis, p 150. Faculty of Agriculture. Sher-e-Kashmir University of Agricultural Sciences and Technology, Kashmir India.

\section{How to cite this article:}

Naresh Thakur, R. K. Devlash and Lata, S. 2021. Screening of QPM Maize Genotypes against Maydis Leaf Blight (Helminthosporium maydis) under Natural Epiphytotic Conditions. Int.J.Curr.Microbiol.App.Sci. 10(02): 1949-1955. doi: https://doi.org/10.20546/ijcmas.2021.1002.233 